\title{
E-learning During COVID-19 Pandemic: Obstacles Faced Nursing Students and Its Effect on Their Attitudes While Applying It
}

\author{
Gehan Mohamed Abd El-Hamed Diab ${ }^{1, ~ *, ~ N a h i d ~ F o u a d ~ E l g a h s h ~}{ }^{2}$ \\ ${ }^{1}$ Department of Nursing Administration, Faculty of Nursing, Menoufia University, Shebin El-Kom, Egypt \\ ${ }^{2}$ Department of Medical Surgical Nursing, Faculty of Nursing, Menoufia University, Shebin El-Kom, Egypt \\ Email address: \\ diabgehan@yahoo.com (G. M. A. El-Hamed D.), fouadnahid@yahoo.com (N. F. Elgahsh) \\ ${ }^{*}$ Corresponding author
}

To cite this article:

Gehan Mohamed Abd El-Hamed Diab, Nahid Fouad Elgahsh. E-learning During COVID-19 Pandemic: Obstacles Faced Nursing Students and Its Effect on Their Attitudes While Applying It. American Journal of Nursing Science. Vol. 9, No. 4, 2020, pp. 295-309.

doi: 10.11648/j.ajns.20200904.33

Received: July 25, 2020; Accepted: August 7, 2020; Published: August 17, 2020

\begin{abstract}
Background: E-learning is the use of the internet and its related devices for educational purposes without geographical restrictions, especially after the outbreak of the coronavirus pandemic, which led to a disruption of education in the classrooms in Egypt and around the world. Teaching and learning via the internet is a novel experience for most teachers and students. Aim: to investigate the effect of obstacles faced nursing students on their attitudes towards e-learning while applying it during COVID-19 pandemic. Design: A descriptive correlational research design. Setting: The study was conducted at Faculty of Nursing, Menoufia University, Egypt. Subjects: A stratified random sample technique was employed for the selection of $30 \%$ from the students in each of the four academic years enrolled in Faculty of Nursing, Menoufia University during the academic year 2019/2020. Tools: Interviewing questionnaire, attitude towards e-learning scale, and obstacles of e-learning questionnaires. Results: The results revealed that overall, $61.6 \%$ of students had negative attitudes towards e-learning. There was the highest level of total obstacles present among academic students in the first year were (67.6\%) and the lowest level of total obstacles present among academic students in the fourth year was (55.7\%) that faced nursing students during using e-learning. the most common dimensions of obstacles to e-learning were infrastructure and technology, technical and management support, and instructors' characteristics $(87.1 \%, 85.2 \%$, and $82.9 \%$, respectively). Conclusions: There was a high statistically significant negative correlation between obstacles facing nursing students, and their attitudes toward e-learning. Recommendations: The Board Directors of the Faculty of Nursing must take the necessary measures to improve electronic learning and teaching during the closure. Also, a systematic strategy should be followed to implement e-learning since it is a new experience for Menoufia University.
\end{abstract}

Keywords: Attitude, COVID-19, E-Learning, Nursing Students, Obstacles

\section{Introduction}

Nowadays, with the rapid growth of knowledge, a new approach has been developed to provide educational content and facilitate interaction between the learner and the teacher around the world using the computer network known as elearning, and thus universities around the world attempt to take the maximum benefit out from the technological revolutions and provide a better teaching-learning environment for various Students, teachers, and administrations $[1,2]$.

After the World Health Organization declared a state of a global emergency due to the outbreak of the COVID-19 pandemic and the Egyptian government has restricted community mobilization to prevent the spread of the disease [3]. Teachers in different countries began to use e-learning in education and teaching for students during this period. Universities around the world are trying to make the most of the technological revolution and provide a better educational learning environment for different stakeholders [4]. 
E-learning is defined as "Learning facilitated and supported through the use of information and communications technology". It can cover a spectrum of activities from the use of technology to support learning as part of a 'blended' approach (a combination of traditional and e-learning approaches), to learning that is delivered entirely online. Whatever the technology, however, learning is the vital element [5].

Electronic learning is a powerful tool that transforms the traditional method of learning because it strengthens the capacity of teaching and learning [6]. It also provides interactivity and active learning, which promotes collaboration and idea-sharing among students and instructors [7]. E-learning can be more flexible and offers a substitution learning of the traditional classroom model and it is a process to enhance study by gaining or supporting the distribution of knowledge, through several technological methods such as audio chatting, video conferencing, and online discussion [8].

E-learning has an important method in education for its efficiency in providing education with a cost-effective solution for ease of accessibility at anytime and anywhere for universities and lecturers, and students [9, 10, 11]. Positive developments in internet and telecommunications technologies have removed time, distance and space barriers and have created a lot of free time in learning and teaching activities and these are fundamental changes in the learning environment [12].

The proliferation of online learning programs is changing the way teachers view and engage with learning worldwide because of increased online education opportunities [13]. Consequently, e-learning is an opportunity to learn without restrictions due to geographical or temporal constraints. So, e-learning is a good option for lifelong learning through enhanced access to education [14]. Technology creates sustainable opportunities for the academic and professional growth of people and their role as participants and beneficiaries of institutional and social activities [15].

E-learning provides the technical and logistical benefits to learners in terms of flexibility, comfort and ease of virtual learning, and students may not necessarily need to attend a pre-scheduled classroom lecture, which allows them the freedom and choice and save their time and money to travel to the campus [16].

Although the e-learning providing for the higher education institutions many educational benefits. Conversely, there remain many challenges and obstacles which obstruct using it's effectively. The process of integrating e-learning into teaching and learning can be a complex procedure that may face several difficulties that are sometimes called barriers or obstacles to integrating e-learning [17].

The obstacles to using e-learning are classified into three groups. The first is called "personal challenges." This group includes factors associated with internal personality traits, behavior characteristics and habits. The second group is "attitudinal inhibitors". The internal variables that are most relevant to users 'attitudes and perspectives regarding e- learning features and the third group include a set of "contextual inhibitors" related to external variables that include a lack of ICT skills and organizational support in the use of learning techniques [18].

Higher education institutions all over the world face a variety of challenges related to the successful implementation, maintenance and development of online programs. Challenges affecting online learning in the Middle East include low internet penetration, low public appreciation for online learning, and a lack of online educational repositories [13]. Furthermore, challenges lead to failure of online education are institutional factors such as lack of understanding of online education, patterns of online learning, lack of management support for online education, number of students enrolled, and faculty qualifications [19].

In a previous study for Salloum et al. [20], it investigated the factors that influenced university students' acceptance of e-learning systems, and the study proposed a new model that examined the impact of innovation, quality, trust, and knowledge as key factors that enhance the acceptance of elearning. In another previous study was discussing the barriers that affect the implementation of e-learning and these barriers were classified into four critical dimensions: learners and teachers, infrastructure, technology, and institutional management. [21].

The COVID-19 pandemic had affected faculties, students, and teachers and the Ministry of Higher Education in Egypt has recognized the needs of implementation E-Learning in public universities to maintain the teaching and learning process. The Universities have implemented e-learning although the universities had little or no experience in elearning and not prepared for e-resources for the teaching and learning process faced difficulties and obstacles especially when teachers and students do not understand how to use online applications [22].

\subsection{Significant of the Study}

In light of the conditions that pass through Egypt and with the World Health Organization declaring the COVID-19 pandemic [3] and the lifting of preventive measures in many Arab countries, which included the closure of schools and universities entirely in some countries, and called on the Ministry of Higher Education in Egypt to using e-learning as a means to ensure the continuity of the educational process and not to lose an academic year for students. Educational institutions are presented with surmounting challenges in its education system and this pandemic will have an impact on the educational and there will be a drop especially in national examinations [23]. Therefore, the Faculty of Nursing, Menoufia University, sought to introduce and apply an elearning system to complete the teaching of courses for all students of the Faculty of Nursing. From the researcher's review of the literature, no studies were investigating the actual obstacles facing students while using the e-learning system So, the present study aimed to investigate the effect of obstacles faced nursing students on their attitudes towards e-learning while applying it during the COVID-19 pandemic 
to address and overcome these obstacles and to enhance the use of e-learning later as an essential rather than an emergency educational tool. Also, the results of this research might be leading to provide clear insights that could be contributing to the effective implementation of E-learning in the Egypt Higher Education System.

\subsection{Aim of the Study}

The aim of this study was to investigate the effect of obstacles faced nursing students on their attitudes towards elearning while applying it during COVID-19 pandemic.

\subsection{Research Question}

1. What are the nursing students' attitudes towards elearning?

2. What are the common obstacles faced by nursing students during applying e-learning?

3. What is the correlation between obstacles faced by nursing students and their attitudes towards e-learning?

4. Is there a relation between the students' demographics characters, obstacles faced, and their attitude towards elearning?

\section{Subject and Method}

\subsection{Research Design}

A descriptive correlational research design was utilized.

\subsection{Variables of the Study}

\subsubsection{Independent Variable}

E-learning obstacles dimensions which included: Learners' characteristics, Technical and Management support, Infrastructure and technology, Curriculum content, and Instructors' characteristics.

\subsubsection{Dependent Variable}

Attitude towards e-learning.

\subsection{Setting}

The study was conducted at Faculty of Nursing, Menoufia University, Egypt.

\subsection{Subjects}

A stratified random sample technique was employed for the selection of $30 \%$ from the students in each of the four academic years enrolled in the Faculty of Nursing, Menoufia University during the academic year 2019/2020. The sample size was 627 student (192 were in the first year, 160 were in the second year, 144 were in the third year and 131 were in the fourth year) out of 2089 students enrolled in the first to fourth years $(636,535,481,437$ respectively) enrolled in Baccalaureate nursing program, faculty of nursing, Menoufia University. All undergraduate nursing students accept participation enrolled in the first to fourth years in the above mentioned setting.

\subsubsection{Inclusion Criteria}

Students were willing to participate in the study and used electronic learning and enrolled in the academic year 20192020 .

\subsubsection{Exclusion Criteria}

Students were not accepting to participate in the study.

\subsection{Tools for Data Collection}

To fulfill the aim of the study, three tools were used for data collection.

\subsubsection{First Tool: Assessment Sheet}

This sheet was designed by the researchers based on relevant literature $[24,25]$. It included personal characteristics related to the subjects as age, gender, residence, marital status, academic years, devices for elearning activities, internet facility at home, and years of experience in using a computer.

\subsubsection{Second Tool: Attitude Towards E-learning Scale}

It was developed by the researchers based on relevant literature $[26,27]$. It consisted of 18 questions to assess the attitudes of nursing students toward e-learning. It contained three domains: E-learning usefulness 6 items, E-learning ease of use 6 items, and behavioral intension 6 items.

Scoring system:

The subjects' response was rated on a five-point Likert Scale from "1" (strongly disagree) to "5" (strongly agree). The score of the items was summed-up and the total divided by the number of the items, giving a mean score for each domain of the e-learning were calculated, and mean overall scores were calculated as well, summing all three domains gives an overall score for student attitudes toward e-learning. These scores were converted into a percent score. The scores of less than $60 \%$ were considered negative attitudes, while the scores of $60 \%$ and more were considered positive attitudes toward e-learning.

\subsubsection{Third Tool: Obstacles of E-learning Questionnaire}

It was developed by the researchers based on relevant literature [28, 29, and 30]. It consisted of 35 questions to identify obstacles facing nursing students during applying the e-learning system in the COVID-19 pandemic. It contains five dimensions: Learners' characteristics 5 items, Technical and Management support 5 items, Infrastructure and technology 5 items, Curriculum content 5 items and Instructors' characteristics dimension 5 items.

Scoring system:

The subjects' response was rated on a five-point Likert Scale from " 1 " (strongly disagree) to " 5 " (strongly agree). The score of the items was summed-up and the total divided by the number of the items, giving a mean score for each dimension of the obstacles of e-learning was calculated. These scores were converted into a percent score. The scores of $60 \%$ and more it means that obstacles occurrence were present and while the scores of less than $60 \%$ it means that obstacles occurrence were absent during applying e-learning system. 


\subsection{Validity and Reliability of the Instrumentation}

\subsubsection{Validity}

Tools of data collection were translated into Arabic and reviewed for their content validity by five experts who were selected to test the content and face validity of the instruments. The panel included two experts from Nursing Administration department, one expert from Community Health Nursing department (Menoufia University), and one expert from Faculty of Education (Menoufia University), and one expert from Nursing Education department (Cairo University). Necessary modifications and deleting of some questions were done to reach the final valid version of the tools.

\subsubsection{Reliability}

The tools were tested for reliability by measuring their internal consistency using Cronbach's alpha coefficient method. This turned to be $(\alpha=0.90)$ for e-learning attitude tool; $(\alpha=0.85)$ for e-learning obstacles tool. Thus indicates a high degree of reliability for the study tools.

\subsection{Pilot Study}

A pilot study was conducted after the development of the tools and before starting the actual data collection. The pilot study was done on $10 \%$ of the sample who were included in the main study sample because they did not add any modifications to the study tools.

\subsection{Fieldwork}

Data was collected upon two months started from the first of April 2020 until the end of May 2020. The questionnaire was published through an e-mail containing a Word file sent to all student participants who were chosen according to the availability and the possibility of electronic communication with them. The email to the student recipients helped provide familiarization with the goal of the study, which contained an informed consent statement. The consent statement also informed the recipients about the researchers' name and contact details either through E-mail, Facebook, or WhatsApp. This information allowed students the opportunity to contact with the researchers if they had any questions or concerns regarding the study. The statement also makes clear that participation in the study is optional. Recipients who began a survey were informed that they could quit participating at any time with no consequences.

\subsection{Administrative and Ethical Consecrations}

Written approval was obtained from the Dean of the Nursing Faculty, Menoufia University to collect data from the students nursing college. The study was conducted with careful attention to ethical standards of research and rights of the participants to accept or refuse to contribute in this study and that their information will be treated with confidentiality and for the purpose of research. The respondents' anonymity was maintained as they weren't required to mention their names.

\subsection{Statistical Analysis}

The data were collected and tabulated into the personal computer. Statistical analysis was done using Statistical Package for Social Science (SPSS/version 23). Quantitative data were expressed as mean and standard deviation $(\mathrm{X} \pm \mathrm{SD})$. Qualitative data were expressed as number and percentage. A comparison was performed using chi-square test and ANOVA test. Correlation between variables was evaluated using Pearson's correlation coefficient (r). P-value at 0.05 was used to determine the level of significance.

\section{Results}

Table 1: Shows the demographic characteristics of the study subjects. As shown in the table, the nearly equal percentage of nursing students was from each academic year. Regarding age, more than half of the students were equal 20 years or less and the mean age was $19.34 \pm 1.46$. Moreover, this table revealed that the highest percentage of nursing students $(58.9 \%)$ were female and $(68.7 \%)$ from a rural area and the majority was unmarried. Concerning devices for elearning activities, the majority of nursing students (90.4\%) had devices for e-learning activities and (64.1\%) of the students use the mobile device for their e-learning, and $(60.1 \%)$ had Internet facility at home. Regarding years of experience in using a computer, more than half of the students had experienced more than five years using a computer.

Table 2: Presents the mean score of attitude towards elearning items among the studied students. As indicated from the table regarding the e-learning usefulness domain, the highest mean score $(3.24 \pm 0.30 \& 3.12 \pm 0.26$ respectively) among the third and second year were in the item of "elearning contents are informative" and the highest mean score $(3.13 \pm 0.38 \& 3.02 \pm 0.34$ respectively) were in the item of "e-learning enhances my learning efficiency". Also, the highest mean scores $(3.01 \pm 1.26)$ among the third year were in the item of "e-learning is a useful learning tool in providing distance education". However, regarding the elearning ease of use domain, the highest mean score (3.21 $\pm 1.02 \& 3.20 \pm 1.00$ respectively) among the second and fourth years were in the item of "e-learning provides flexible interaction with teachers and friends". As regards the behavioral intension e-learning domain the highest mean score $(3.51 \pm 0.02, \quad 3.44 \pm 0.06 \quad \& 3.43 \pm 0.01$ respectively) among the third, second and fourth year were in the items of "e-learning is efficient as a teaching method" and the lowest mean score $(1.10 \pm 0.52,1.40 \pm 1.04 \& 1.42 \pm 1.00$ respectively) among the first, second and fourth year were in the items of " e-learning is better than face-to-face education in the learning process".

Table 3: Shows mean scores of e-learning domains and total attitude score toward e-learning as reported by the nursing students. As indicated from the table, the highest mean score toward total attitude $(53.62 \pm 11.04)$ for the third academic year students consider the only positive attitude. 
While the lowest mean score of the studied subjects was the first academic (34.10 \pm 8.02$)$. There was a statistically significant difference between the students' academic years and their attitudes toward e-learning. Also, it was observed from the table that all nursing students of all academic years had a low mean score related to the easiness of using the elearning domain. Otherwise, the third and second-year students had the highest mean score $(23.74 \pm 4.62 \&$ $19.56 \pm 4.36$ respectively) regarding the e-learning usefulness domain and third-year students had the highest mean score (16.49 \pm 3.04$)$ regarding the behavioral intension domain of elearning.

Figure 1: Illustrates nursing students' attitudes toward elearning according to their academic years. The highest percentage among first and fourth-year students had negative attitudes toward e-learning $(72.4 \%$ \& $68 \%$ respectively), while more than half of students in the second year have negative attitudes $(54.4 \%)$. The only students in the third year have positive attitudes toward e-learning, but by slightly more than half $(50.7 \%)$.

Figure 2: Illustrates the distribution of nursing students according to an overall attitude toward e-learning. As indicated by the figure, the highest percentage of nursing students $(61.6 \%)$ had a negative attitude towards e-learning. While $(38.4 \%)$ of the nursing students had a positive attitude towards using e-learning

Table 4: Presents distribution of e-learning obstacles items regarding learners' characteristics, technical and management support, and technical and management support dimensions from the nursing students' perspective. As indicated from the table regarding e-learning obstacles items regarding learners' characteristics, the highest percentage of nursing students (69.6\% \& 68.6\% respectively) agree/strongly agree that lack time management skills to keep up with the pace of their courses and lack of sufficient knowledge and skill in the use of e-learning. However, regarding the items related to the dimension of technical and management support, the majority of nursing students $(92.6 \%, 90.2 \%, \& 86.2 \%$ respectively) agree/strongly agree that system errors and lack of access to the e-learning platform, the college does not provide technical support for using e-learning and lack technical assistance to handle technological problems. As regards the items related to the dimension of Infrastructure and technology, the majority of nursing students $(96.6 \%$, $93.0 \% \& 90.2 \%$ respectively) agree/strongly agree that low bandwidth connections with frequent breakdowns and lack of proper training before using e-learning platform and they suffered from e-learning system design is not flexible and difficult to use.

Table 5: Presents distribution of e-learning obstacles items regarding curriculum content and instructors' characteristics dimensions from the nursing students' perspective. As indicated from the table regarding e-learning obstacles items regarding curriculum content, the highest percentage of nursing students $(84.9 \%, \quad \& 83.1 \%$ respectively) agree/strongly agree that difficult to understand the contents of the subject through e-learning and concerns about the practical nature of some courses are not offered electronically. However, regarding the items related to the instructors' characteristics dimension, the highest percentage of nursing students $(90.2 \%, 86.7 \%$ \& $83.1 \%$ respectively) agree/strongly agree that Difficulty contacting with academic staff when at home, teachers prefer conventional ways of teaching and research, and teacher's delay in submitting courses online on-time affects their performance.

Figure 3: Illustrates the percentage of obstacles faces nursing students during using e-learning according to academic years. There was the highest level of total obstacles present among academic students in the first year were $(67.6 \%)$ and the lowest level of total obstacles present among academic students in the fourth year was $(55.7 \%)$.

Figure 4: Illustrates ranking nursing students about dimensions of obstacles of e-learning during applying it according to their perception. It showed that infrastructure and technology, technical and management support, and instructors' characteristics were the most common dimensions of obstacles to e-learning $(87.1 \%, 85.2 \%$, \& $82.9 \%$ respectively) and the least obstacles of e-learning dimensions were in the curriculum content dimension and learners' characteristics dimension were (69.7\& 61.9\% respectively).

Table 6: Denoted the relation between the academic years of the studied subjects and obstacles of e-learning as reported by the nursing students. As shown in the table, there were statistically significant differences between the academic years of the studied subjects regarding e learning obstacles. Also, it was observed from the table that all nursing students of all academic years had the highest mean score related to infrastructure and technology obstacles and technical and management support obstacles, and curriculum content obstacles. Otherwise, the third and second-year students had the lowest mean score $(17.61 \pm 3.14 \& 18.0 \pm 3.72$ respectively) regarding learners' characteristics obstacles and fourth-year students had the lowest mean score $(24.63 \pm 2.1)$ regarding instructors' characteristics obstacles.

Table 7: Indicates the correlation coefficient (r) between elearning obstacles dimensions and total scores of attitudes towards e-learning among nursing students. It displayed that there was a statistically significant negative correlation between the total score of attitude toward e- learning and the scores of five dimensions of the obstacles regarding elearning, and there was a significant positive correlation between learners' characteristics dimension and curriculum content and instructors' characteristics dimension. Also, there was a highly significant positive correlation between technical and management support and infrastructure and technology dimension regarding e-learning obstacles.

Table 8: Indicates the relation between the nursing students' demographics characteristics, obstacles faced them and their attitudes toward e-learning. The table reflected the highest percentages of nursing students had a negative attitude toward e-learning regarding age, gender, academic years, marital status, and residence, devices for e-learning activities, internet facility at home and experience in using a computer. Also, it 
reflects that a highly statistically significant difference in all variables except residence and marital status was no statistically significant difference. Also, the table illustrated the highest percentages of nursing students had faced e-learning obstacles during applying it regarding age, gender, academic years, marital status, residence, devices for e-learning activities, internet facility at home and experience in using a computer. Also, no statistically significant difference between the students' demographic variables and the obstacles they faced them, but statistically significant difference regarding age, gender variables and devices to be used in conducting elearning activities.

Table 1. Demographic characteristics of the study subjects $(n=627)$.

\begin{tabular}{|c|c|c|}
\hline \multirow{2}{*}{ Demographic characteristics } & \multicolumn{2}{|c|}{ Nursing Students $(n=627)$} \\
\hline & NO. & $\%$ \\
\hline \multicolumn{3}{|l|}{ Age (years): } \\
\hline$\leq 20$ & 321 & 51.2 \\
\hline $21: 22$ & 204 & 23.5 \\
\hline$\geq 23$ & 102 & 16.3 \\
\hline Mean \pm SD & & $19.34 \pm 1.46$ \\
\hline Range & & $19.0-23.0$ \\
\hline \multicolumn{3}{|l|}{ Gender: } \\
\hline Male & 258 & 41.1 \\
\hline Female & 369 & 58.9 \\
\hline \multicolumn{3}{|l|}{ Residence: } \\
\hline Rural & 431 & 68.7 \\
\hline Urban & 196 & 31.3 \\
\hline \multicolumn{3}{|l|}{ Marital status: } \\
\hline Married & 29 & 4.6 \\
\hline Not married & 598 & 95.4 \\
\hline \multicolumn{3}{|l|}{ Academic years: } \\
\hline First year & 192 & 30.6 \\
\hline Second year & 160 & 25.5 \\
\hline Third year & 144 & 23 \\
\hline Fourth year & 131 & 20.9 \\
\hline \multicolumn{3}{|l|}{ Devices for e-learning activities: } \\
\hline Computer & 81 & 13 \\
\hline Laptop & 58 & 9.2 \\
\hline Mobile & 402 & 64.1 \\
\hline Tablet & 26 & 4.1 \\
\hline No Device & 60 & 9.6 \\
\hline \multicolumn{3}{|l|}{ Internet facility at home: } \\
\hline Yes & 377 & 60.1 \\
\hline No & 250 & 39.9 \\
\hline \multicolumn{3}{|l|}{ Computer Use (years): } \\
\hline $5<$ & 298 & 47.5 \\
\hline$\geq 5$ & 329 & 52.5 \\
\hline
\end{tabular}

Table 2. Mean score of attitude towards e-learning items among the studied students (n=627).

\begin{tabular}{|c|c|c|c|c|}
\hline \multirow[b]{2}{*}{ Electronic learning items } & \multicolumn{4}{|c|}{ Academic years Mean \pm SD } \\
\hline & $\begin{array}{l}1^{\text {st }} \text { year } \\
(n=192)\end{array}$ & $\begin{array}{l}2^{\text {nd }} \text { year } \\
(n=160)\end{array}$ & $\begin{array}{l}3^{\text {rd }} \text { year } \\
(n=144)\end{array}$ & $\begin{array}{l}4^{\text {th }} \text { year } \\
(n=131)\end{array}$ \\
\hline \multicolumn{5}{|l|}{ E-learning usefulness } \\
\hline 1. E-learning contents are informative. & $2.62 \pm 0.23$ & $3.12 \pm 0.26$ & $3.24 \pm 0.30$ & $2.86 \pm 0.22$ \\
\hline 2. E-Learning enhances my learning efficiency. & $2.52 \pm 0.33$ & $3.02 \pm 0.34$ & $3.13 \pm 0.38$ & $2.76 \pm 0.31$ \\
\hline 3. E-Learning encourages me to search for additional information on the topic of learning. & $1.30 \pm 0.33$ & $1.81 \pm 0.61$ & $2.03 \pm 0.65$ & $1.55 \pm 0.35$ \\
\hline 4. E-learning is a useful learning tool in providing distance education. & $2.23 \pm 1.15$ & $2.73 \pm 1.22$ & $3.01 \pm 1.26$ & $2.47 \pm 1.17$ \\
\hline 6. E-learning enables me to accomplish the learning activities more quickly. & $1.18 \pm 0.28$ & $1.68 \pm 0.77$ & $2.14 \pm 0.80$ & $1.42 \pm 0.26$ \\
\hline \multicolumn{5}{|l|}{ E-learning ease of use } \\
\hline 7. It is easy for me to handle e-learning content. & $1.11 \pm 0.90$ & $2.01 \pm 0.17$ & $2.11 \pm 0.15$ & $2.07 \pm 0.08$ \\
\hline 8. E-learning gives all the materials I need in my studies. & $2.40 \pm 0.97$ & $2.87 \pm 1.00$ & $3.04 \pm 0.98$ & $2.94 \pm 0.91$ \\
\hline 9. E-learning gives facilities to manage my time efficiently. & $1.09 \pm 1.01$ & $2.05 \pm 0.15$ & $2.07 \pm 0.13$ & $2.01 \pm 0.06$ \\
\hline 10. E-learning makes my learning process easier. & $1.26 \pm 0.91$ & $1.72 \pm 1.05$ & $1.74 \pm 1.02$ & $1.74 \pm 0.96$ \\
\hline 11.E-learning reduces students educational cost. & $1.38 \pm 0.06$ & $1.81 \pm 0.44$ & $1.85 \pm 0.43$ & $1.78 \pm 0.35$ \\
\hline \multicolumn{5}{|l|}{ Behavioral intension } \\
\hline 13.E-learning is efficient as teaching method. & $2.41 \pm 0.61$ & $3.44 \pm 0.06$ & $3.51 \pm 0.02$ & $3.43 \pm 0.01$ \\
\hline 14. E learning is better than face-to-face education in learning process. & $1.10 \pm 0.52$ & $1.40 \pm 1.04$ & $1.71 \pm 0.98$ & $1.42 \pm 1.00$ \\
\hline 15.I prefer to use e-books for my studies. & $1.12 \pm 0.72$ & $1.48 \pm 0.71$ & $1.62 \pm 0.67$ & $1.44 \pm 0.65$ \\
\hline 16. I interested in studying courses that use e-learning. & $1.27 \pm 0.73$ & $1.59 \pm 0.72$ & $2.76 \pm 0.62$ & $1.58 \pm 0.67$ \\
\hline
\end{tabular}




\begin{tabular}{|c|c|c|c|c|}
\hline \multirow[b]{2}{*}{ Electronic learning items } & \multicolumn{4}{|c|}{ Academic years Mean \pm SD } \\
\hline & $\begin{array}{l}1^{\text {st }} \text { year } \\
(n=192)\end{array}$ & $\begin{array}{l}2^{\text {nd }} \text { year } \\
(n=160)\end{array}$ & $\begin{array}{l}3^{\text {rd }} \text { year } \\
(n=144)\end{array}$ & $\begin{array}{l}4^{\text {th }} \text { year } \\
(n=131)\end{array}$ \\
\hline 17. I recommend using e learning system for other students. & $1.39 \pm 0.06$ & $1.73 \pm 0.08$ & $1.89 \pm 0.09$ & $1.71 \pm 0.02$ \\
\hline 18. I enjoy using e learning system on my course & $2.12 \pm 0.02$ & $2.01 \pm 0.17$ & $2.07 \pm 0.13$ & $2.11 \pm 0.02$ \\
\hline
\end{tabular}

Table 3. Mean score of e-learning domains and total attitude toward e learning as reported by the nursing students ( $n=627)$.

\begin{tabular}{llllllll}
\hline \multirow{2}{*}{ E-learning domains } & \multicolumn{2}{l}{$\mathbf{1}^{\text {st }}$ year (192) } & $\mathbf{2}^{\text {nd }}$ year (160) & $\mathbf{3}^{\text {rd }}$ year (144) & $\mathbf{4}^{\text {th }}$ year (131) & Total (627) \\
\cline { 2 - 7 } & Max & Mean \pm SD & Mean \pm SD & Mean \pm SD & Mean \pm SD & Mean \pm SD \\
\hline E-learning usefulness & 27 & $13.91 \pm 3.34$ & $19.56 \pm 4.36$ & $23.74 \pm 4.62$ & $14.93 \pm 3.31$ & $18.62 \pm 3.81$ \\
E-learning ease of use & 24 & $9.34 \pm 3.71$ & $12.36 \pm 3.84$ & $13.47 \pm 3.71$ & $14.24 \pm 3.29$ & $12.35 \pm 3.63$ & 3 \\
Behavioral intension & 23 & $10.85 \pm 2.63$ & $13.46 \pm 3.27$ & $16.49 \pm 3.04$ & $9.43 \pm 2.95$ & $12.63 \pm 2.87$ \\
Total Score & 74 & $34.10 \pm 8.02$ & $45.39 \pm 10.27$ & $53.62 \pm 11.04$ & $38.47 \pm 7.45$ & $43.23 \pm 9.21$ & 2 \\
value
\end{tabular}

(*) statistically significant at $\mathrm{p}<0.05(* *)$ highly statistically significant at $\mathrm{p} \leq 0.001$

Table 4. Distribution of e-learning obstacles items regarding learners' characteristics, technical and management support, and technical and management support dimensions from the nursing students' perspective $(n=627)$.

\begin{tabular}{|c|c|c|c|}
\hline E-learning obstacles & $\begin{array}{l}\text { ++ Disagree / } \\
\text { Disagree }\end{array}$ & Neutral & ++Agree / Agree \\
\hline \multicolumn{4}{|l|}{ Learners' characteristics dimension } \\
\hline 1. Lack of sufficient knowledge and skill in the use of e-learning. & $14.2 \%$ & $17.2 \%$ & $68.6 \%$ \\
\hline 2. Lack of devices to use for e-learning. & $77.5 \%$ & $8.9 \%$ & $13.6 \%$ \\
\hline 3. Lack confidence and shyness from learning online. & $26.5 \%$ & $28.1 \%$ & $45.4 \%$ \\
\hline 4. No internet connection. & $40.5 \%$ & $4.5 \%$ & $55.0 \%$ \\
\hline 5. Lack time management skills to keep up with the pace of the course. & $11.7 \%$ & $18.7 \%$ & $69.6 \%$ \\
\hline 7. Lack language skills and typing skills for online learning & $41.3 \%$ & $8.2 \%$ & $50.5 \%$ \\
\hline \multicolumn{4}{|l|}{ Technical and Management support dimension } \\
\hline 8. Faced with system errors and lack of access to the e-learning platform & $4.5 \%$ & $2.9 \%$ & $92.6 \%$ \\
\hline 9. The slowness of network is an obstacle to my learning online & $5.3 \%$ & $11.6 \%$ & $83.1 \%$ \\
\hline 10. Lack of support services such as tutors & $42.1 \%$ & $2.7 \%$ & $55.2 \%$ \\
\hline 11. The e-learning system is unavailable most of the time. & $20.4 \%$ & $9.1 \%$ & $70.5 \%$ \\
\hline 12. The college does not provide technical support for using e-learning & $8.1 \%$ & $1.7 \%$ & $90.2 \%$ \\
\hline \multicolumn{4}{|l|}{ Infrastructure and technology dimension } \\
\hline 15. Low bandwidth connections with frequent breakdowns & $1.3 \%$ & $2.1 \%$ & $96.6 \%$ \\
\hline 16. Lack of proper training before using e-learning platform. & $1.8 \%$ & $5.2 \%$ & $93.0 \%$ \\
\hline 17. The cost of internet fees/charges from the private cafe' impede e-learning & $26.5 \%$ & $8.1 \%$ & $65.4 \%$ \\
\hline 18. Lack of counselling during taking e-learning courses & $10.6 \%$ & $4.5 \%$ & $84.9 \%$ \\
\hline 19. E-learning system design is not flexible and difficult to use & $8.1 \%$ & $1.7 \%$ & $90.2 \%$ \\
\hline 20.Erratic power supply at home hinders my use of e-learning resources & $32.2 \%$ & $4.5 \%$ & $63.3 \%$ \\
\hline 21. The rules and program directions in using online discussion are difficult to me. & $26.5 \%$ & $8.1 \%$ & $65.4 \%$ \\
\hline
\end{tabular}

Table 5. Distribution of e-learning obstacles items regarding curriculum content and instructors' characteristics dimensions from the nursing students' perspective $(n=627)$.

\begin{tabular}{|c|c|c|c|}
\hline E-learning obstacles & $\begin{array}{l}\text { ++ Disagree / } \\
\text { Disagree }\end{array}$ & Neutral & $\begin{array}{l}++ \text { Agree } / \\
\text { Agree }\end{array}$ \\
\hline \multicolumn{4}{|l|}{ Curriculum content dimension } \\
\hline $\begin{array}{l}\text { 22. Learning and teaching resources that are available on the e-learning system are not in accordance with the } \\
\text { curriculum. }\end{array}$ & $40.5 \%$ & $4.5 \%$ & $55.0 \%$ \\
\hline 23. Difficult to access e-resources from the e-platform when at home & $34.8 \%$ & $6.2 \%$ & $59.0 \%$ \\
\hline 24. Difficult to learn the contents of my subject using e-learning & $15.6 \%$ & $7.9 \%$ & $76.5 \%$ \\
\hline 25. Difficult to understand the contents of the subject through e-learning. & $10.6 \%$ & $4.5 \%$ & $84.9 \%$ \\
\hline 26. Disproportion of e-learning with curriculum content & $40.5 \%$ & $4.5 \%$ & $55.0 \%$ \\
\hline 27. Concerns about the practical nature of some courses are not offered electronically & $5.3 \%$ & $11.6 \%$ & $83.1 \%$ \\
\hline $\begin{array}{l}\text { 28. Lecture notes are supported by multimedia tools (flash animations, simulations, videos, audios, etc.). } \\
\text { Instructors' characteristics dimension }\end{array}$ & $46.0 \%$ & $16.2 \%$ & $37.8 \%$ \\
\hline 29. Instructors do not have sufficient knowledge and skill to use e-learning & $10.6 \%$ & $4.5 \%$ & $84.9 \%$ \\
\hline 30. My teachers not confident in using e-learning & $33.3 \%$ & $14.5 \%$ & $52.2 \%$ \\
\hline 31. Lack of clear instructions from my teacher. & $30.7 \%$ & $1.3 \%$ & $68.0 \%$ \\
\hline 32. Lack of timely feedback from instructor & $12.9 \%$ & $10.7 \%$ & $76.4 \%$ \\
\hline 33. My teachers prefer conventional ways of teaching and research. & $8.8 \%$ & $4.5 \%$ & $86.7 \%$ \\
\hline 34. My teacher's delay in submitting courses online on time affects my performance & $5.3 \%$ & $11.6 \%$ & $83.1 \%$ \\
\hline 35. Difficulty contacting with academic staff when at home & $8.1 \%$ & $1.7 \%$ & $90.2 \%$ \\
\hline
\end{tabular}




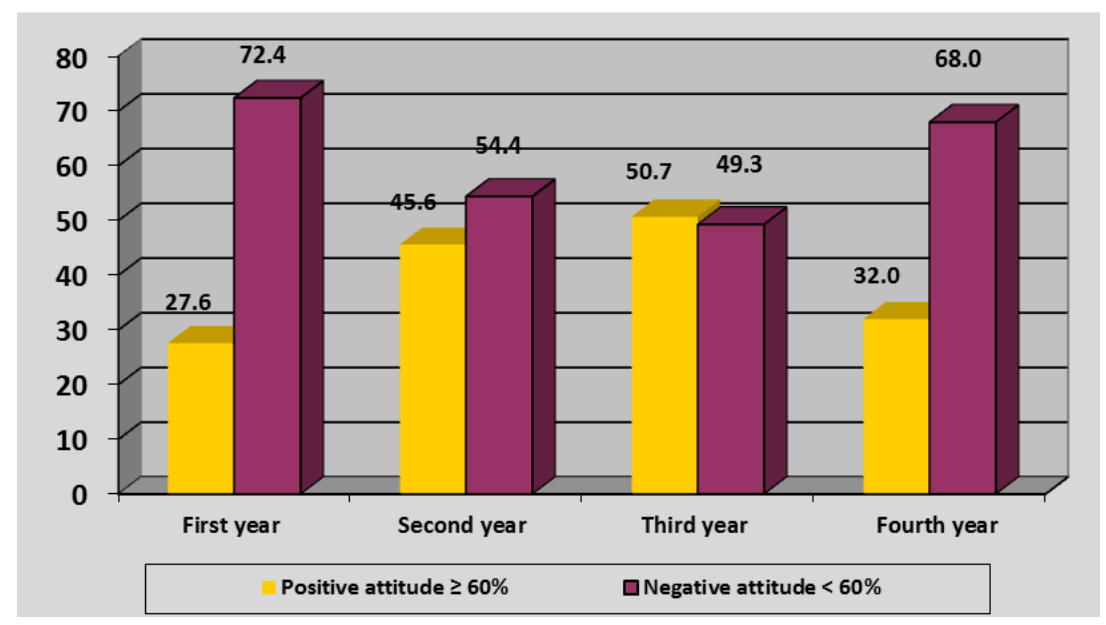

Figure 1. Nursing students' attitudes toward e-learning according to their academic years ( $n=627)$.

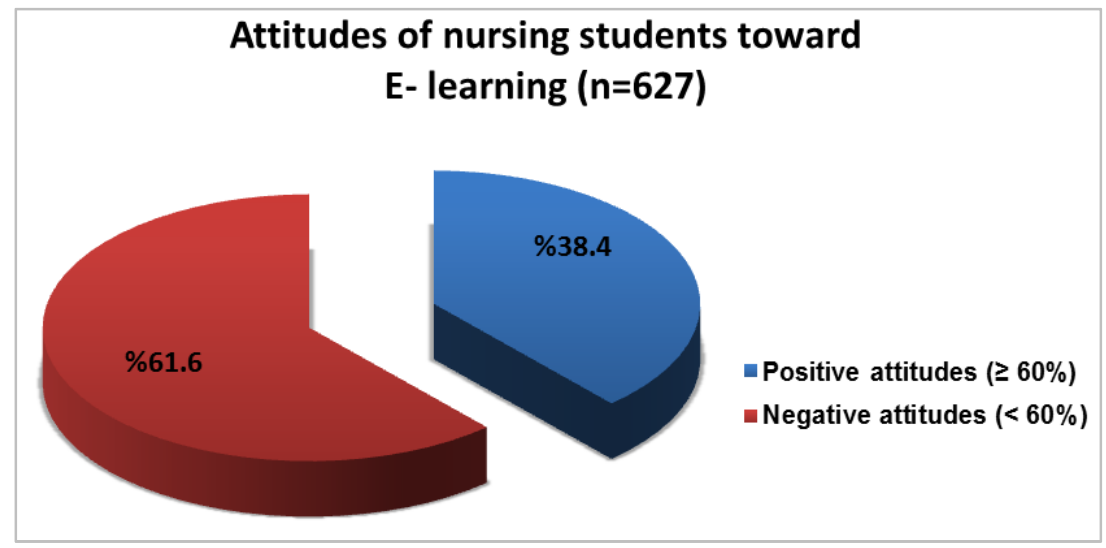

Figure 2. Distribution of nursing students according to overall attitude toward e learning ( $n=627)$.

Table 6. Relation between academic years of the studied subject and obstacles of e-learning as reported by the nursing students ( $n=627)$.

\begin{tabular}{|c|c|c|c|c|c|c|c|}
\hline \multirow{2}{*}{ Obstacles Dimensions } & \multicolumn{5}{|c|}{ Academic years } & \multirow{2}{*}{ ANOVA } & \multirow{2}{*}{ P-value } \\
\hline & Max & $1^{\text {st }}$ year $(n=192)$ & $2^{\text {nd }}$ year $(n=160)$ & $3^{\text {rd }}$ year $(n=144)$ & $4^{\text {th }}$ year $(n=131)$ & & \\
\hline Learners' characteristics & 28 & $25.87 \pm 4.54$ & $18.0 \pm 3.72$ & $17.61 \pm 3.14$ & $19.62 \pm 3.82$ & 17.32 & $0.001 * *$ \\
\hline Technical and Management support & 35 & $30.21 \pm 2.31$ & $30.72 \pm 5.45$ & $28.67 \pm 3.88$ & $26.64 \pm 2.31$ & 16.42 & $0.001 * *$ \\
\hline Infrastructure and technology & 35 & $31.12 \pm 3.52$ & $33.67 \pm 4.74$ & $30.63 \pm 5.41$ & $29.64 \pm 3.52$ & 14.73 & $0.001 * *$ \\
\hline Curriculum content & 30 & $28.64 \pm 2.36$ & $25.70 \pm 4.51$ & $25.70 \pm 4.51$ & $21.27 \pm 4.54$ & 15.29 & $0.001 * *$ \\
\hline Instructors' characteristics & 35 & $30.21 \pm 4.52$ & $29.84 \pm 5.42$ & $29.32 \pm 2.1$ & $24.63 \pm 2.1$ & 20.95 & $0.001 * *$ \\
\hline
\end{tabular}

$(*)$ statistically significant at $\mathrm{p}<0.05(* *)$ highly statistically significant at $\mathrm{p} \leq 0.001$

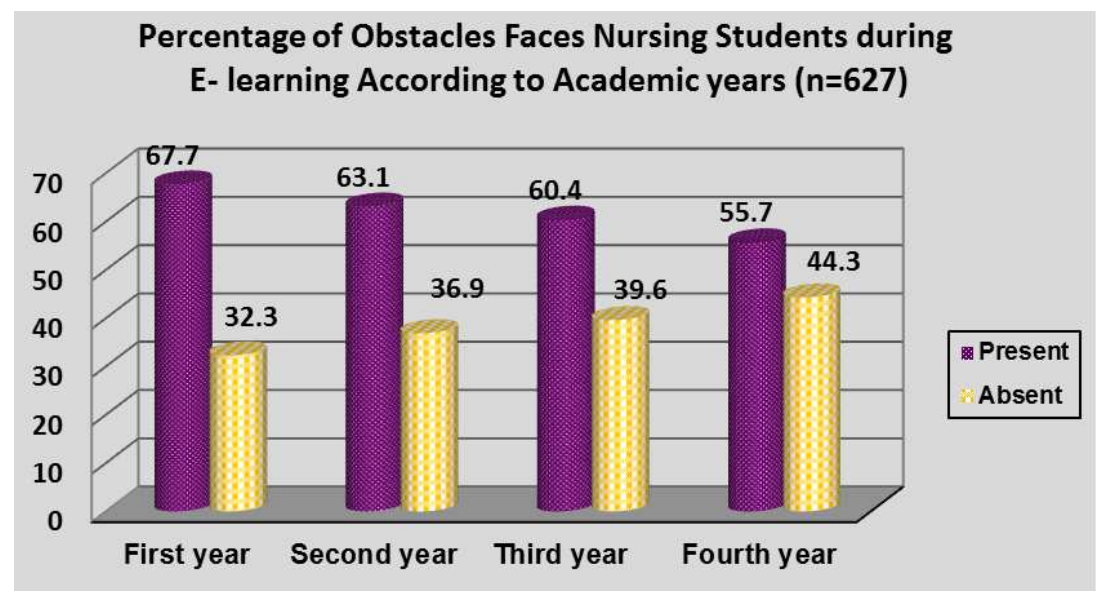

Figure 3. Percentage of obstacles faces nursing students during using e- learning according to academic years ( $n=627$ ). 


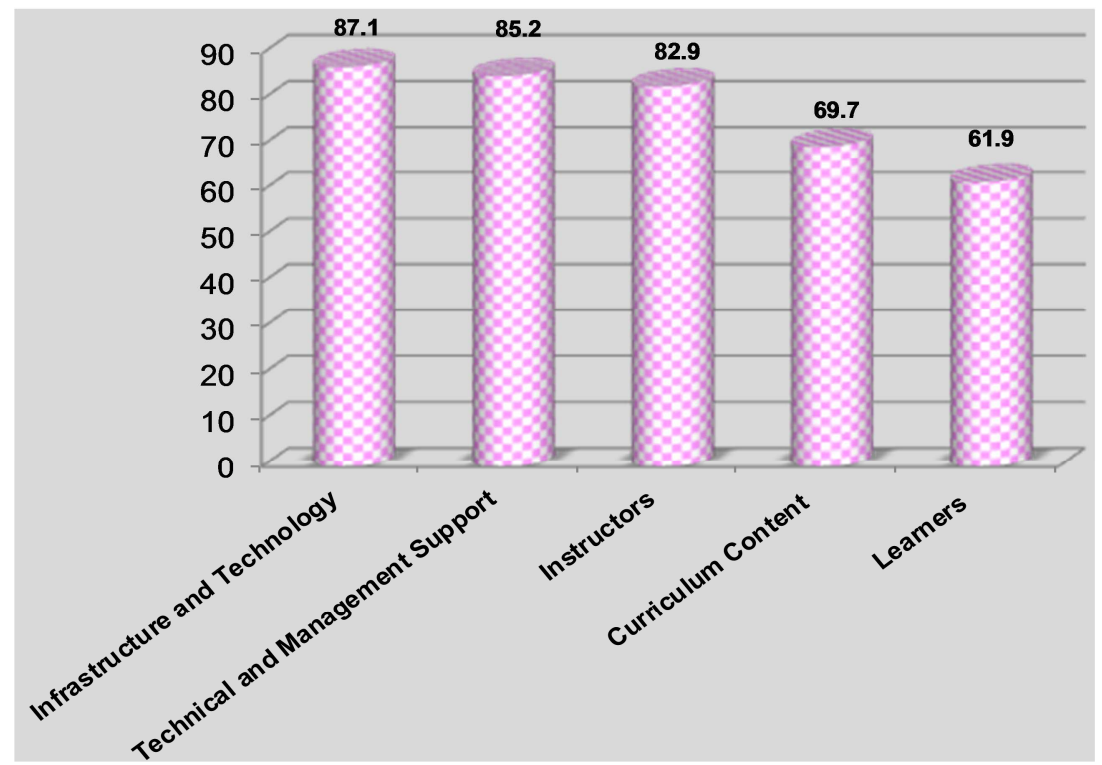

Figure 4. Ranking of obstacles of E- Learning during applying it according to nursing students' perception.

Table 7. Correlation coefficient (r) between e-learning obstacles dimensions and attitudes towards e-learning among nursing students ( $n=627)$.

\begin{tabular}{|c|c|c|c|c|c|c|c|c|c|c|c|c|}
\hline \multirow[t]{2}{*}{ Variables } & \multicolumn{2}{|c|}{$\begin{array}{l}\text { Total score of e- } \\
\text { learning attitude }\end{array}$} & \multicolumn{2}{|c|}{$\begin{array}{l}\text { Learners' } \\
\text { characteristics }\end{array}$} & \multicolumn{2}{|c|}{$\begin{array}{l}\text { Technical and } \\
\text { Management support }\end{array}$} & \multicolumn{2}{|c|}{$\begin{array}{l}\text { Infrastructure } \\
\text { and technology }\end{array}$} & \multicolumn{2}{|c|}{$\begin{array}{l}\text { Curriculum } \\
\text { content }\end{array}$} & \multicolumn{2}{|c|}{$\begin{array}{l}\text { Instructors' } \\
\text { characteristics }\end{array}$} \\
\hline & $\mathbf{r}$ & $\mathbf{P}$ & $\mathbf{r}$ & $\mathbf{P}$ & $\mathbf{r}$ & $\mathbf{P}$ & $\mathbf{r}$ & $\mathbf{P}$ & $\mathbf{r}$ & $\mathbf{P}$ & $\mathbf{r}$ & $\mathbf{P}$ \\
\hline Total score of e-learning attitude & 1 & & & & & & & & & & & \\
\hline Learners' characteristics & -0.55 & $0.000^{* *}$ & 1 & & & & & & & & & \\
\hline Technical and Management support & -0.37 & $0.01^{*}$ & 0.54 & 0.062 & 1 & & & & & & & \\
\hline Infrastructure and technology & -0.62 & $0.001^{* *}$ & 0.59 & 0.074 & 0.62 & $0.001^{* *}$ & 1 & & & & & \\
\hline Curriculum content & -0.23 & $0.005^{*}$ & 0.42 & $0.01^{*}$ & 0.68 & $0.001^{* *}$ & 0.73 & 0.11 & 1 & & & \\
\hline Instructors' characteristics & -0.68 & $0.000^{* *}$ & 0.48 & $0.001^{* *}$ & 0.72 & 0.06 & 0.62 & 0.23 & 0.98 & $0.001^{* *}$ & 1 & \\
\hline
\end{tabular}

(*) statistically significant at $\mathrm{p}<0.05(* *)$ highly statistically significant at $\mathrm{p} \leq 0.001$

Table 8. Relation between the nursing students' demographics characteristics, obstacles faced and their attitudes toward e-learning ( $n=627)$.

\begin{tabular}{|c|c|c|c|c|c|c|c|c|c|c|c|c|}
\hline \multirow{3}{*}{ Demographic characteristics } & \multicolumn{4}{|c|}{ Overall Attitude toward E learning } & \multirow{3}{*}{$\mathbf{X}^{2}$} & \multirow{3}{*}{$P$ value } & \multicolumn{4}{|c|}{ E learning Obstacles } & \multirow{3}{*}{$\mathbf{X}^{2}$} & \multirow{3}{*}{$P$ value } \\
\hline & \multicolumn{2}{|c|}{$\begin{array}{l}\text { Positive } \\
(\text { no }=241)\end{array}$} & \multicolumn{2}{|c|}{$\begin{array}{l}\text { Negative } \\
(\text { no }=386)\end{array}$} & & & \multicolumn{2}{|c|}{$\begin{array}{l}\begin{array}{l}\text { Present } \\
(n o=391)\end{array} \\
(n=0\end{array}$} & \multicolumn{2}{|c|}{$\begin{array}{l}\text { Absent } \\
(\text { no }=236)\end{array}$} & & \\
\hline & No & $\%$ & No & $\%$ & & & No & $\%$ & No & $\%$ & & \\
\hline \multicolumn{13}{|l|}{ Age (years): } \\
\hline$\leq 20$ & 102 & 31.8 & 219 & 68.2 & \multirow{3}{*}{8.34} & \multirow{3}{*}{$0.001 * *$} & 246 & 76.6 & 75 & 23.4 & \multirow{3}{*}{14.8} & \multirow{3}{*}{$0.001 * *$} \\
\hline $21: 22$ & 90 & 44.1 & 114 & 55.9 & & & 99 & 48.5 & 105 & 51.5 & & \\
\hline$\geq 23$ & 49 & 48.0 & 53 & 52.0 & & & 46 & 45.0 & 56 & 55.0 & & \\
\hline \multicolumn{13}{|l|}{ Gender: } \\
\hline Male & 117 & 45.3 & 141 & 54.7 & \multirow{3}{*}{6.09} & \multirow{3}{*}{$0.001 * *$} & 144 & 55.8 & 114 & 44.2 & \multirow{3}{*}{5.82} & \multirow{3}{*}{$0.01 *$} \\
\hline Female & 124 & 33.6 & 245 & 66.4 & & & 247 & 66.9 & 122 & 33.1 & & \\
\hline Residence: & & & & & & & & & & & & \\
\hline Rural & 166 & 38.5 & 265 & 61.5 & \multirow{3}{*}{2.1} & \multirow{3}{*}{0.13} & 270 & 62.6 & 161 & 37.4 & \multirow{3}{*}{1.9} & \multirow{3}{*}{0.17} \\
\hline Urban & 75 & 38.3 & 121 & 61.7 & & & 121 & 61.7 & 75 & 38.3 & & \\
\hline Marital status: & & & & & & & & & & & & \\
\hline Married & 10 & 34.5 & 19 & 65.5 & \multirow{3}{*}{2.5} & \multirow{3}{*}{0.11} & 20 & 69.0 & 9 & 31.0 & \multirow{3}{*}{2.6} & \multirow{3}{*}{0.10} \\
\hline Not married & 231 & 38.6 & 367 & 61.4 & & & 371 & 62.0 & 227 & 38.0 & & \\
\hline Academic years: & & & & & & & & & & & & \\
\hline First year & 53 & 27.6 & 139 & 72.4 & & & 130 & 67.7 & 62 & 32.3 & & \\
\hline Second year & 73 & 45.6 & 87 & 54.4 & 148 & $0001 * *$ & 101 & 63.1 & 59 & 36.9 & 486 & 051 \\
\hline Third year & 73 & 50.7 & 71 & 49.3 & 14.8 & $0.001^{* *}$ & 87 & 60.4 & 57 & 39.6 & 4.86 & .051 \\
\hline Fourth year & 42 & 32.0 & 89 & 68.0 & & & 73 & 55.7 & 58 & 44.3 & & \\
\hline Devices for e-learning activities: & & & & & & & & & & & & \\
\hline Computer & 31 & 38.3 & 50 & 61.7 & & & 55 & 68.0 & 26 & 32.0 & & \\
\hline Laptop & 22 & 38.0 & 36 & 62.0 & & & 41 & 70.7 & 17 & 29.3 & & \\
\hline Mobile & 175 & 43.5 & 227 & 56.5 & 17.1 & $0.001 * *$ & 234 & 58.2 & 168 & 41.8 & 7.1 & $0.008 *$ \\
\hline Tablet & 12 & 46.2 & 14 & 53.8 & & & 15 & 58.0 & 11 & 42.0 & & \\
\hline No Device & 1 & 1.7 & 59 & 98.3 & & & 46 & 76.7 & 14 & 23.3 & & \\
\hline Internet facility at home: & & & & & & & & & & & & \\
\hline
\end{tabular}




\begin{tabular}{|c|c|c|c|c|c|c|c|c|c|c|c|c|}
\hline \multirow{3}{*}{ Demographic characteristics } & \multicolumn{4}{|c|}{ Overall Attitude toward E learning } & \multirow{3}{*}{$\mathbf{X}^{2}$} & \multirow{3}{*}{ P value } & \multicolumn{4}{|c|}{ E learning Obstacles } & \multirow{3}{*}{$\mathbf{X}^{2}$} & \multirow{3}{*}{ P value } \\
\hline & \multicolumn{2}{|c|}{$\begin{array}{l}\text { Positive } \\
(\text { no }=241)\end{array}$} & \multicolumn{2}{|c|}{$\begin{array}{l}\text { Negative } \\
(\mathrm{no}=386)\end{array}$} & & & \multicolumn{2}{|c|}{$\begin{array}{l}\text { Present } \\
(\text { no }=391)\end{array}$} & \multicolumn{2}{|c|}{$\begin{array}{l}\text { Absent } \\
(\text { no }=236)\end{array}$} & & \\
\hline & No & $\%$ & No & $\%$ & & & No & $\%$ & No & $\%$ & & \\
\hline Yes & 203 & 53.8 & 174 & 46.2 & \multirow{2}{*}{6.23} & \multirow{2}{*}{0.072} & 221 & 58.6 & 156 & 41.4 & \multirow{2}{*}{1.8} & \multirow{2}{*}{0.14} \\
\hline No & 38 & 15.2 & 212 & 84.2 & & & 170 & 68.0 & 80 & 32.0 & & \\
\hline Computer Use (years): & & & & & & & & & & & & \\
\hline$<5$ & 33 & 11.0 & 265 & 89.0 & 6.83 & $0.001 * *$ & 186 & 62.4 & 112 & 37.6 & 1.9 & 0.18 \\
\hline
\end{tabular}

(*) statistically significant at $\mathrm{p}<0.05(* *)$ highly statistically significant at $\mathrm{p} \leq 0.001$

\section{Discussion}

Undoubtedly, the implementation of e-learning systems in higher education has enabled a fundamental change in teaching and learning practice. The success or failure of elearning across an organization depends on several factors. This field of science facilitates the provision of the facilities for designing new scientific environments, which was not possible in the past. Therefore, the evaluation of e-learning systems is vital to ensure successful implementation, effective use, and positive impacts on learners [31].

Therefore, the aim of the present study was to investigate the effect of obstacles faced nursing students on their attitudes towards e-learning while applying it during the COVID-19 pandemic. Four questions were answered in the present study. The first question was: what are the nursing students' attitudes towards e-learning? The second was: what are the common obstacles faced by nursing students during applying e-learning? The third question was: what is the correlation between obstacles faced by nursing students and their attitudes towards e-learning? And the fourth question was: what is the relation between the students' demographics characters, obstacles faced and their attitude towards e-learning?

Before discussing the results related to answering the study questions, the light should be directed to socio-demographic characteristics of the study subjects illustrated in table 1 . Demographic characteristics indicated that the nearly equal percentage of nursing students was from each academic year. Regarding age, more than half of the students were equal 20 years or less and the mean age was $19.34 \pm 1.46$. Moreover, this table revealed that the highest percentage of nursing students $(58.9 \%)$ were female and $(68.7 \%)$ from a rural area and the majority was unmarried. Concerning devices for elearning activities, the majority of nursing students (90.4\%) had devices for e-learning activities and (64.1\%) of the students use a mobile device for their e-learning and (60.1\%) had Internet facility at home. Regarding years of experience in using computer, more than half of the students had experienced more than five years using a computer.

For answering the first question was: what are the nursing students' attitudes towards e-learning? The most important results of the current study were that the highest percentages of nursing students approximately two-thirds of the study sample had negative attitudes and more than one third had positive attitudes towards using the e-learning system to complete their studies and curricula during the COVID-19 pandemic. From the researchers' point of view, the overall attitude towards e-learning for students was highly negative considered as a form of resistance and rejection from students for a sudden change from face-to-face learning to electronic learning. Also, the students are not ready for the practice of e-learning which is a new experience for students of the Faculty of Nursing at Menoufia University.

This result is similar to Abbasi et al., [32] who found that the overall $77 \%$ of students have negative perceptions towards e-learning. Also, Obaid Ullah et al., [33] reported that negative approach among students regarding online learning. Besides, recent systematic reviews of Betihavas et al., [34] and Hew and Lo, [35] indicate that e-learning produces neutral or positive academic outcomes in undergraduate nurses and health professional education.

Regarding the overall attitude toward e-learning among nursing students according to their academic years, the current study showed that the highest percentage among first and fourth-year students had negative attitudes toward using e-learning, while more than half of students in the second year have negative attitudes. The only students in the third year slightly more than half have positive attitudes and the highest mean score was $(53.62 \pm 11.04)$. From the researchers' point of view, the overall attitude of the third year students towards e-learning was positive because the faculty members in the Department of Maternal and Newborn Health Nursing use e-learning in teaching from previous years and they were the first to do the electronic courses system in their department. While the highest percentage of first-year students has negative attitudes toward using e-learning, it may be because they are new to college and have no experience using the Internet in their previous school years.

This result agreed with Mahmoud et al., [36] who found that second and third years students had positive attitudes toward e-learning. In addition, Bhatia, [37] reported that the attitude can be negative if the student cannot adapt to the new system because the new form of education not fits the students' needs and characteristics.

Regarding the total mean scores of the three domains of students' attitudes toward e-learning, the present study showed that the highest mean scores were the e-learning usefulness domain followed by behavioral intension and then e-learning ease of use domain respectively as reported by the nursing students. Moreover; the present study showed that third and second-year students respectively had the highest mean score related to the e-learning usefulness domain. Otherwise, all nursing students of all academic years had a low mean score related to the easiness of using the e-learning 
domain. Besides, third-year students had the highest mean score regarding the behavioral intension domain of elearning. All of the e-learning domains among the nursing students had statistically significant differences.

From the researchers' point of view, the students' perceptions that e-learning was useful at enhancing their academic competence and providing distance education are a major factor influencing their overall attitude towards elearning. Also, almost all students have a low average score regarding the ease of use of e-learning due to lack of technical assistance for students to handle technological problems and the difficulty of using e-learning because it is a new experience for them, especially for first-year students. Also, when students feel the e-learning system is easy to use and useful this will enhance their attitude towards e-learning.

This finding aligns with Al-Samarraie et al., [11] found that users' perceptions that e-learning was useful at enhancing their performance positively influenced their attitude towards e-learning. Also, Mislinawati and Nurmasyitah [38] shows that the students perceived the elearning web-based module to be useful in improving their understanding, independence, self-discipline, motivation to learn, and interactions with each other and with the teacher. In addition, Salloum et al., [20] and Aljaraideh and Al Bataineh [39] reported that easiness and user-friendliness of e-learning systems will have an impact on individuals' acceptance and intention to use such systems.

For answering the second question was: what are the common obstacles faced by nursing students during applying e-learning? The findings of the present study revealed five dimensions of the obstacles regarding e-learning as contributors to obstructing during applying it. These obstacles have been identified as; learners' characteristics dimension, technical and management support, infrastructure and technology dimension, curriculum content dimension and instructors' characteristics dimension. These five obstacles dimensions are similar among nursing students in different academic years.

The most prevalent obstacle faced by nursing students were infrastructure and technology, technical and management support, and instructors' characteristics while, the least obstacles were the curriculum content and learners' characteristics dimension as reported by nursing students.

According to the results of the current study, the first important obstacle was infrastructure and technology. The majority of nursing students reported the lack of infrastructure at the nursing faculty to provide guidance, counseling, training before using an e-learning platform, and low bandwidth connections with frequent breakdowns also, the e-learning system design is not flexible and difficult to use. From the researchers' point of view, all these are significant obstacles hindering the effective application of e-learning and the strategic direction is the central feature of the organizational infrastructure that supports students to accept e-learning and the effectiveness of the learning system.

This finding concurs with Aljaraideh and Al Bataineh [39] who found that the major barriers students encounter are poor infrastructure. Also, Al-Azawei et al., [40] founded that most students $(62.5 \%)$ agreed that low internet bandwidth is one of the issues hindering the successful application of e-learning in Iraq. In addition, Vershitskaya et al., [41] found that poverty and lack of ICT infrastructure are the main problems that have been identified as challenges of e-learning.

As for the second important obstacle identified in the present study were obstacles of technical and management support. The majority of nursing students indicating that faced with system errors and lack of access to the e-learning platform and lack of technical assistance to handle technological problems are significant obstacles in the effective use of e-learning. These findings are in the same line with Mohammadzadeh et al., [42] who found that technical support services will motivate continuity elearning. In addition, Ali et al., [43] reported that one of the main barriers to the use of e-learning is technical difficulties such as lack of technical support, poor and outdated computer systems and connectivity issues.

Regarding the third important obstacle in e-learning was the characteristics of instructors' obstacles. The majority of nursing students reported difficulty contacting with academic staff when at home, and teachers do not have sufficient knowledge and skill to use e-learning and they delay in submitting courses online on time and also, teachers prefer conventional ways of teaching and research. From the researchers' point of view, instructors are content experts and facilitators of course delivery and manage students' learning. Therefore, the non-use of e-teaching systems by instructors will affect learners' attitudes toward using e-learning and any obstacle in instructor's characteristics preventing students from applying e-learning effectively.

This result is congruent with Osman et al., [44] mentioned that instructors play a pivotal role in helping the student to achieve educational objectives and they are highly active using the e-learning system by providing fast response, motivation support, suggestion, and assessment can positively increase student satisfaction. Also, Touray et al., [45] who stated that if teachers want to succeed in using technology in their classes, they should have a positive attitude towards the new technology implementation.

Otherwise, according to the results, the least obstacles regarding e-learning identified in the present study were curriculum content and learners' characteristics obstacles as reported by nursing students. About two-thirds of the study sample reported the difficulty of their understanding of the contents of the subject through e-learning and the practical application of some courses that are not offered electronically, and they lack sufficient knowledge and skill in using e-learning and also lack the time management skill to keep up with the pace of the course.

From the researchers' point of view; students need support to develop their skills to participate effectively in e-learning opportunities and students' previous experiences may affect their use of technology in their learning. Tarus et al., [46] explained that the successful implementation of e-learning cannot be achieved without developing individual skills. 
Also, Green and Huntington [47] stated that one of the main benefits of e-learning is its flexibility for learners. Additionally, Mayerova and Rosicka [48] reported that students with basic computer skills will feel more interested and motivated to use e-learning, meanwhile, students with no basic computer skills will feel more difficult to get engaged because they need to learn how to use the application first.

For answering the third question was: what is the correlation between obstacles faced by nursing students and their attitudes towards e-learning? The present study' findings revealed that there was a highly significant negative correlation between the total score of attitude to e-learning and each of the five dimensions of the obstacles to e-learning (learners' characteristics, technical and management support, infrastructure and technology, curriculum content, and instructors' characteristics).

The result was supported by Mtebe and Raphael [49] found that system quality, service quality, and instructor quality had a significant positive effect on learners' satisfaction. Moreover, this result was consistent with Mahmodi \& Moghadam [50] who reported that a positive and significant relationship between student-professor interaction with attitude toward online interaction. In addition, Kisanga [51] stated that teachers are the key stakeholders of education and their perception of adopting elearning also has a significant impact on students' attitude formation towards e-learning.

More ever, the present study indicated that the learners' characteristics obstacle had a statistically significant positive correlation with dimensions of instructors' characteristics and curriculum content obstacles. The result was supported by Mtebe and Raphael [49] who found that instructor quality has been found to have a significant positive effect on learners' satisfaction with an e-learning system. In the same context, these results agree with Alone and Mugabirwe [52] who found that a significant, positive correlation between the quality of the content in the implemented e-learning and learners' attitude. Meanwhile, Harrandi [53] found that carefully designed course content has a positive effect on student motivation towards e-learning.

The current study indicated that there was a statistically significant positive correlation with dimensions of technical and management support obstacles and infrastructure and technology obstacles, this results consistent with Naveed et al., [54] stated that for successful implementation of elearning, organizations need to ensure appropriate Hardwares, Soft-wares, internet connectivity, and technical support system. Also, the current study indicated that there was a statistically significant positive correlation with dimensions of technical and management support obstacles and curriculum content obstacles. This finding is similar to Mailizar et al., [55] who found the strongest correlation was between the school level e-learning barriers and curriculum level e-learning barrier.

For answering the fourth question was: was: what is the relation between the students' demographics characters, obstacles faced and their attitude towards e-learning?
Regarding the relation between the students' demographics and the obstacles, they faced while using e-learning. The present study found that there are statistically significant differences in the obstacles of e-learning due to the gender variable in favor of females, and the results indicate that females faced greater obstacles when using e-learning compared to male students. Also, the study found that there are statistically significant differences in the obstacles to elearning due to the lack of devices to be used in conducting e-learning activities.

This finding contradicts with Lowes et al., [56] which indicate that female are more interested in using e-learning than their peers. Also, the study found that there are statistically significant differences in the obstacles to e-learning due to the age variable in favor of the youngest age. This study contradicts with Amro et al., [57] which indicates age has no impact on academic achievement by using online learning.

Regarding the relation between the students' demographics and their attitude towards e-learning, the present study found that male students have more positive attitudes toward elearning than female students and there are statistically significant differences between gender and their attitudes towards e-learning. This result was congruent with Rafiq [58] who pointed out that the male students' attitude is more positive than the female students' attitude at higher educational levels towards e-learning. But this result was inconsistent with Jan \& Mattoo [59] who showed that no significant influence of gender, on the attitude towards e learning. Also, the present study found statistically significant differences in the attitude towards e-learning due to the age variable in favor of the youngest age and the results indicate that the younger students have a negative attitude towards e-learning compared to the older students. Ramadan et al., [60] found that there was no significant association between the gender and age of participants and their attitudes towards using E-learning.

Moreover, the current study revealed that there was a statistically significant difference between experiences with using computer and academic years of students with their attitudes towards the use of e-learning. This result consistent with Xhaferi et al., [61] who reported there are statistically significant differences in the levels of attitudes towards elearning between students of the different year of study students. Also, Peytcheva-Forsyth et al., [62] who indicated that learner' skills and experience with ICT might significantly impact on attitude towards online learning.

Finally, address and overcome these obstacles faced by nursing students while applying e-learning platforms and improving e-teaching will affect the learners' attitude towards e-learning and will encourage them to use the internet in their education and communicate with their teachers and colleagues.

\section{Conclusion}

In light of the present study findings, it can conclude that the overall attitude of nursing students toward e-learning was negative. The highest percentage among first and fourth-year 
students had negative attitudes toward e-learning $(72.4 \%$ \& $68 \%$ respectively) while, more than half of students in the second year have negative attitudes $(54.4 \%)$. The only students in the third year have positive attitudes toward e-learning. Additionally; there was the highest level of total obstacles present among academic students in the first year were $(67.6 \%)$ and the lowest level of total obstacles present among academic students in the fourth year was $(55.7 \%)$. The most common obstacles faced nursing students were infrastructure and technology followed by technical and management support and instructors' characteristics. There was a high statistically significant negative correlation between obstacles facing nursing students, and their attitudes toward e-learning. Finally, there was a statistically significant difference between nursing students' attitudes and their all demographic variables except residence and marital status. No statistically significant difference between the students' demographic variables, and the obstacles faced them except age, gender variables and devices to be used in conducting e-learning activities.

\section{Recommendations}

In the light of the present study the following recommendations were suggested:

1. The Board of Directors of the Faculty of Nursing must take the necessary measures to improve electronic learning and teaching during the closure.

2. A systematic strategy should be followed to implement e-learning since it is a new experience for Menoufia University.

3. Preparing professional technical staff to maintain elearning and support learners and instructors to handle technological problems.

4. Training programs should be conducted to students and instructors on how to using e-learning platforms and improve their self-confidence in their use.

5. Cooperating with other universities that have made progress in applying e-learning and taking them as a benchmark to be followed.

6. Encourage the application of e-learning through the use of e-learning as a standard for evaluating the performance of faculty members.

7. The Government provides financial support, development of infrastructure, and facilitation of electronic resources.

8. More researches are needed for the investigation of faculty members' attitudes to e-learning.

9. More researches are needed to identify barriers to elearning implementation from the perspective of faculty members.

\section{References}

[1] Al-Gamdi, M., and Samarji, A. (2016). Perceived Barriers towards e-Learning by Faculty Members at a Recently Established University in Saudi Arabia. Int. J. Inf. Educ. Technol., 6 (1): 23-28. Retrieved from: https://doi.org/10.7763/IJIET.2016.V6.652
[2] Bahramnezhad, F., Asgari, P., Ghiyasvandian, S., Shiri, M., and Bahramnezhad, F. (2016). The Learners' Satisfaction of Elearning: A Review Article. American Journal of Educational Research, 4 (4): 347-352.

http://pubs.sciepub.com/education/4/4/8/

[3] World Health Organization. (2020). Statement on the meeting of the International Health Regulations (2005) Emergency Committee regarding the outbreak of novel coronavirus (2019-nCoV). Retrieved on 27 April 2020 from https://bit.ly/2RwodiW

[4] Zhang, YU. (2020). COVID-19 crisis is an opportunity to try out online HE. 14 March 2020 Retrieved from: https://www.universityworldnews.com/post.php?story=20200 31013551895

[5] Joint Information Systems Committee, JISC. (2020). Available from: https://intranet.royalholloway.ac.uk/staff/teaching/elearning/overview-of-e-learning/defining-e-learning.aspx

[6] Alfraih, M., and Alanezi, S. (2016). Accounting students' perceptions of effective faculty attributes. Journal of International Education in Business, 9 (2): 123-142.

[7] Alsabawy, A., Cater-Steel, A., and Soar, J. (2016). Determinants of perceived usefulness of e-learning systems. Computers in Human Behavior, 64: 843-858. ISSN 07475632. doi: 10.1016/j.chb.2016.07.065.

[8] Odit-Dookhan, K. (2018). Attitude towards E-Learning: The Case of Mauritian Students in Public TEIS. International Journal of Social Sciences, 4 (3): 628-643. https://dx.doi.org/10.20319/pijss.2018.43.628643

[9] George, P., Papachristou, N., Belisario, JM. (2014). Online eLearning for undergraduates in health professions: A systematic review of the impact on knowledge, skills, attitudes and satisfaction. J Glob Health, 4 (1): 1-17.

[10] Asiry, MA. (2017). Dental students' perceptions of an online learning. Saudi Dent J, 29 (4): 167-170.

[11] Al-Samarraie, H., Teng, BK., Alzahrani, AI. (2018). Elearning continuance satisfaction in higher education: a unified perspective from instructors and students. Studies in Higher Education, $43 \quad$ (11): 2003-19. https://doi.org/10.1080/03075079.2017.1298088

[12] Aparicio, M., Bacao, F., and Oliveira, T. (2017). Grit in the path to e-learning success. Comput. Human Behav., vol. 66: 388-399. https://doi.org/10.1016/j.chb.2016.10.009

[13] Palvia, S., Aeron, P., Gupta, P., Mahapatra, D., Ratri, P., Rosner, R. and Sindhi, S. (2018). Online education: Worldwide status, challenges, trends, and implications. Journal of Global Information Technology Management, 21 (4):

233-241. https://doi.org/10.1080/1097198X.2018.1542262

[14] Arasaratnam, S. L., and Northcote, M. (2017). Community in online higher education: Challenges and opportunities. The Electronic Journal of e-Learning, 15 (2): 188-198. Retrieved from http://www.ejel.org/main.html

[15] Schmitt, U. (2016). Redefining knowledge management education with the support of personal knowledge management devices. Smart Education and e-Learning, Springer, Cham, pp. 515-525. 
[16] Bower, M., Dalgarno, B., Kennedy, G. E., Lee, M. J. and Kenney, J. (2015). Design and implementation factors in blended synchronous learning environments: outcomes from a cross-case analysis. Computers \& Education, No. 86, pp. 1-17. https://doi.org/10.1016/j.compedu.2015.03.006

[17] Mahlangu, P. (2018). The good, the bad, and the ugly of distance learning in higher education. In M. Sinecen (Ed.), Trends in e-learning. Intech Open. Retrieved from http://dx.doi.org/10.5772/intechopen.75702

[18] Zamani, E., and Esfijani, A. (2016). Major barriers for participating in online teaching in developing countries from Iranian faculty members' perspectives. Australasian Journal of Educational Technology, 32 (3): 38-49.

[19] Kentnor, HE. (2015). Distance education and the evolution of online learning in the United States. Curriculum and Teaching Dialogue, 17 (1/2): 21-34.

[20] Salloum, S. A., Al-Emran, M., Shaalan, K., and Tarhini, A. (2019). Factors affecting the e-learning acceptance: a case study from UAE. Education and Information Technologies, 24 (1): 509-530.

[21] Quadri, N., Muhammed, A., Sanober, S., Qureshi, M. and Shah, A. (2017). Barriers effecting successful implementation of e-learning in Saudi Arabian universities. International Journal of Emerging Technologies in Learning (iJET), 12 (6): 94-107. https://doi.org/10.3991/ijet.v12i06.7003

[22] Zaharah, Z., Kirilova, G., and Windarti, A. (2020). Impact of Corona Virus Outbreak Towards Teaching and Learning Activities in Indonesia. SALAM: Jurnal Sosial dan Budaya Syar-i, 7 (3): 269- 281. https://doi.org/10.15408/sjsbs.v7i3.15104

[23] Sintema, E. J. (2020). Effect of COVID-19 on the Performance of Grade 12 Students: Implications for STEM Education. Eurasia Journal of Mathematics, Science and Technology Education, $16 \quad$ (7): $\quad$ em1851. https://doi.org/10.29333/ejmste/7893

[24] Liaw, S. (2008). Investigating Students' Perceived Satisfaction, Behavioral Intention, and Effectiveness of ELearning: A Case Study of the Blackboard System. Computers \& Education 51: 864-873.

[25] Akimanimpaye, F. and Fakude, L. P. (2015). Attitudes of undergraduate nursing students towards e-learning at the University of the Western Cape, South Africa. African Journal for Physical, Health Education, Recreation and Dance, Supplement 1: 2 (October), 418-433.

[26] Abbad, M., Morris, D., and Nahlik, D. (2009) Looking under the Bonnet: Factors Affecting Student Adoption of ELearning Systems in Jordan. International Review of Research in Open and Distance Learning, 10 (2): 1-25.

[27] Rhema A. and Miliszewska I. (2014). Analysis of Student Attitudes towards E-learning: The Case of Engineering Students in Libya," Issues in Informing Science and Information Technology, vol. 11, pp. 169-190. Retrieved from: http://iisit.org/Vol11/IISITv11p169-190Rhema0471.pdf

[28] Bhuasiri, W., Xaymoungkhoun, O, Rho, J. and Ciganek, P. (2012). Critical success factors for e-learning in developing countries: A comparative analysis between ICT experts and faculty. Computers and Education, 58 (2): 843-855.

[29] Muilenburg, Y., and Berge, L. (2005). Student barriers to online learning: A factor analytic study. Distance Education,
26 (1): 29-48. https://doi.org/10.1080/01587910500081269

[30] Assareh, A., and Bidokht, M. H. (2011). Barriers to e-teaching and e-learning. Procedia Computer Science, 3, 791-795. https://doi.org/10.1016/j.procs.2010.12.129

[31] Al-Fraihat D., Joy, M., Masa'deh, R., and Sinclair J. (2020). Evaluating E-learning Systems Success: An empirical study. Computers in Human Behavior, vol. 102, 67-86. doi: 10.1016/j.chb.2019.08.004.

[32] Abbasi, S., Ayoob, T., Malik, A., Memon, SI. (2020). Perceptions of students regarding E-learning during Covid-19 at a private medical college. Pak J Med Sci. 36 (COVID19S4): COVID19-S57-S61. https://doi.org/10.12669/pjms.36.COVID19-S4.2766

[33] Obaid Ullah, O., Khan, W., and Khan A. (2017). Students' Attitude towards Online Learning at Tertiary Level. Humanities and Social Sciences (PUTAJ), 25 (1-2): 63-82.

[34] Betihavas, V., Bridgman, H., Kornhaber, R., Cross, M., (2016). The evidence for 'flipping out': a systematic review of the flipped classroom in nursing education. Nurse Educ. Today 38, 15-21. https://doi.org/10.1016/j.nedt.2015.12.010.

[35] Hew, K. F., Lo, C. K., 2018. Flipped classroom improves student learning in health professions education: a metaanalysis. BMC Med. Educ. 18, 38. Retrieved from: https://doi.org/10.1186/s12909-018-1144-z.

[36] Mahmoud, R., El Magrabi, M., \& Mohamed, R. (2015). Faculty of Nursing Teaching Staff members and Students Attitudes toward e-learning. IOSR Journal of Nursing and Health Science, 4 (4): 2320-1940.

[37] Bhatia. P. (2011). Features and Effectiveness of E-learning Tools. Global Journal of Business Management and Information Technology, 1 (1): 1-7.

[38] Mislinawati, V., and Nurmasyitah, M. (2018). Students' perceptions on the implementation of e-learning: Helpful or unhelpful? Paper presented at the 6th South East Asia Design Research International Conference.

[39] Aljaraideh, Y and Al Bataineh, K, (2019). Jordanian Students' Barriers of Utilizing Online Learning: A Survey Study. International Education Studies, 12 (5): 99-108 http://www.ccsenet.org/journal/index.php/ies/article/view/0/39 309

[40] Al-Azawei A, Parslow. P and Lundqvist. K (2016). Barriers and Opportunities of E-Learning Implementation in Iraq: A Case of Public Universities. The International Review of Research in Open and Distributed Learning, 17 (5): 126-146.

[41] Vershitskaya, R., Mikhaylova, V., Gilmanshina I., Dorozhkin, M., and Epaneshnikov, V. (2020). Present-day management of universities in Russia: Prospects and challenges of e-learning. Education and Information Technologies, 25 (1): 611-621.

[42] Mohammadzadeh N, Ghalavandi $\mathrm{H}$, and Abbaszadeh $\mathrm{M}$, (2017). Critical Success Factors for Electronic Learning from the Perspectives of Faculty Members and Experts of Tehran University of Medical Sciences, Tehran, Iran, Using Delphi Method and Analytic Hierarchy Process. Future of medical education journal (FMEJ), 7 (3): 3-8.

[43] Ali, S., Gulliver, S., and Uppal, M. (2018). A conceptual framework highlighting e-learning implementation barriers. Info Tech People. 31 (1): 156-180. 
[44] Osman M, Wahid A and Zakria A, (2018). Assessment of Factors Affecting E-learning: Preliminary Investigation. 1st International Conference on Open Library to Open SocietyAt: Sukhotai Thammatirat Open University, Nonthaburi, Thailand. Retrieved from: https://www.researchgate.net/publication/327666987_Assess ment of Factors Affecting_Elearning_Preliminary_Investigation

[45] Touray, A., Salminen, A., and Mursu, A. (2013). ICT barriers and critical success factors in developing countries. The Electronic Journal on Information Systems in Developing Countries, 56 (7): 1-17.

[46] Tarus, J. K., Gichoya, D., and Muumbo, A. (2015). Challenges of implementing e-learning in Kenya: A case of Kenyan public universities. International Review of Research in Open and Distributed Learning, 16 (1): 120-141.

[47] Green J, and Huntington A, (2017). Online professional development for digitally differentiated nurses: An action research perspective. Nurse Education in Practice, 22, 55-62. https://doi.org/10.1016/j.nepr.2016.11.009

[48] Mayerova, S. H., and Rosicka, Z. (2015). E-Learning Pros and Cons: Active Learning Culture? Social and Behavioral Sciences, 191, 958-962. doi: 10.1016/j.sbspro.2015.04.702

[49] Mtebe, S., and Raphael, C. (2018). Key factors in learners' satisfaction with the e-learning system at the University of Dar es Salaam, Tanzania. Australasian Journal of Educational Technology, 34 (4): 107-122.

[50] Mahmodi, M., and Moghadam, M. (2019). The Correlation between Students' Attitudes and Persistence in E-Learning," Interdisciplinary Journal of Virtual Learning in Medical Sciences, 10 (2): 30-38.

[51] Kisanga D. (2016). Determinants of Teachers' Attitudes towards E-Learning in Tanzanian Higher Learning Institutions," The International Review of Research in Open and Distributed Learning, 17 (5): 109-125.

[52] Alone and Mugabirwe (2019). Barriers and Motivators to Implementation of an E-Learning and Multimedia Technology towards Improving School Education Standards in Mathematics and Health Education in Nakivale Refugee Settlement, Uganda. International Journal of Trend in Scientific Research and Development (IJTSRD) 3 (6). https://zenodo.org/record/3587927\#.XxlGKVUzbIU
[53] Harrandi, S. R. (2015). Effects of e-learning on students' motivation. Social and Behavioral Sciences, 181, 423-430.

[54] Naveed, Q., Muhammed, A., Sanober, S., Qureshi, M., and Shah, A. (2017). Barriers Effecting Successful Implementation of E-Learning in Saudi Arabian Universities. International Journal of Emerging Technologies in Learning (IJET), 12 (6): 94-107.

[55] Mailizar M, Almanthari A, Maulina S, and Bruce S, (2020). Secondary School Mathematics Teachers' Views on Elearning Implementation Barriers during the COVID-19 Pandemic: The Case of Indonesia," Eurasia Journal of Mathematics, Science and Technology Education, 16 (7): 1-9. Retrieved from: https://doi.org/10.29333/ejmste/8240

[56] Lowes, S., Lin, P., and Kinghorn, B. (2016). Gender differences in online high school courses. Online Learning, 20 (4): $100-117$.

[57] Amro, H., Mundy, M., and Kupczynski, L. (2015). The effects of age and gender on student achievement in face-to -face and online college algebra classes. Research in Higher Education Journal, 27, 1-22.

[58] Rafiq, F. (2020) Analyzing Students' Attitude towards ELearning: A Case Study in Higher Education in Pakistan. Pakistan Social Sciences Review, 4 (1): pp. 367-380.

[59] Jan, H., and Mattoo, M. (2018). Attitude towards E-Learning among Research Scholars with respect to the Demographical Variables. A Peer Reviewed Refereed International Research Journal, 4 (1): 38-42.

[60] Ramadan, K., Elatresh, J., Alzain A., and Tokeser U. (2019). An Analysis of Factors affecting Learners' attitudes towards the Integration of E-learning into the Higher Education System in Libya: Case Study; Misurata University," Australian Journal of Basic and Applied Sciences. 13 (10): 55-64.

[61] Xhaferi, G., Bahiti, R., and Farizi, XH. (2018). The Impacts of Demographic Variables of students on attitudes towards elearning in higher education. International Journal of Computer Science and Information Security, 16 (6): 93-98.

[62] Peytcheva-Forsyth, R., Yovkova, B., and Aleksieva, L. (2018). Factors affecting students' attitudes towards online learning The case of Sofia University. https://doi.org/10.1063/1.5082043 